\title{
METHODOLOGICAL APPROACHES AND PRINCIPLES OF ANALYSIS OF CONTRACTS IN THE CONCEPT OF EFFICIENCY OF A COMPANY'S INTERNATIONAL TRADE ACTIVITY
}

\section{O. Martyanova ${ }^{1}$}

\section{Abstract}

The paper is focused on studying the relevant issues of development of a methodological base and an applied toolware for the international trade contract analysis aimed at the increase of efficiency of the international trade activity by business entities.

Keywords: international trade, international trade contract, foreign supplier, criterion, methodology, methodological approach, evaluation, principles of analysis, efficiency.

doi: http:.doi.org/10.15350/UK_3/5/4

Companies enter the international market to find new directions of their development, which explains the wide involvement of business communities of countries into the global relations. Under the contemporary conditions achieving high efficiency of the activity is possible only through active participation both in the domestic market and the international one despite the sanctions introduced by the western countries against Russia as the Russian business participation in the international trade is determined by the World Trade Organization. Russia became a WTO member in 2012. Absence of a uniform methodology of evaluation of a business entity activity in the world market slowed down the achievement of high efficiency, that made the companies-members of the international trade develop a toolware for evaluating efficiency of their international trade activities.

In view of dynamism of this direction of a company's activity, the analysis of its efficiency should involve all components of this business process, including conditions of contracts. This is explained by the fact that in performance of international trade contracts a company forms assets and liabilities constituting its financial state; and exchange rate differences affecting the financial result of a company, conditions for prepayment in import contracts and payments after delivery of goods in export transactions requiring adjustment of the floating capital management, which involve a high risk, occur.

Relevance of selecting the optimal contract for a company is caused by the fact that its provisions are the toolware of mitigation of negative influence of an unstable rate of the national currency and high inflation on the international trade activity. At the same time, contracts with foreign suppliers and buyers are under the close attention of regulating bodies in view of reduction of volumes of export-import transactions and, as a result, foreign exchange proceeds from the sale of raw materials that fell in price. This is confirmed by amendments in the effective legislation. Thus, according to Federal Law No.89-FZ of April 05, 2016 [3], the term of bringing to responsibility for currency offences is increased from

\footnotetext{
${ }^{1}$ Olga Martyanova, Candidate of Economic Sciences, doctoral candidate, Orel State University of Economics and Trade, Russia.
} 
one year up to two years from the date of its commission; the punishment for legal entities that have not returned funds to the territory of Russia in the terms specified by Federal Law No.30-FZ of February 15, 2016 [2] is strengthen.

The analysis of legal literature shows that now the legal framework regulating the international purchases is being actively formed. Thus, business entities may apply the provisions of Federal Law No.44-FZ of April 05, 2016 On the contractual system in the sphere of purchases of goods, works, services for the state and municipal needs [4] taking into account the Civil Code and the Customs Code of the Eurasian Economic Union as a basis for development of the system of internal control over purchases of goods under international trade contracts.

The review of economic literature and our own studies let us state that at present there are several methods that give a possibility to assess efficiency of international trade contracts. Among them there is a methodology recommended by the Ministry of Economy of the Russian Federation in 2000 as well as the methods proposed by V. I. Barilenko [13, p. 298] based on assessment of impact of foreign exchange holdings and liabilities on the financial results of a company's activity; by F. F. Ionova [10, p. 313] assessing efficiency of export contracts by cost indicators including a contract performance ratio; by L. E. Strovsky [9, p. 211] calculating the efficiency of export contract using such indicators as profitability and costs per ruble of exported market products. Despite relative simplicity of the performance indicator calculation the comparison of their values with the data of the previous periods and refusal to consider the cash flows of a company makes it difficult to define the optimal variant of the international trade contract by these methods, which requires their refinement as under uncertainty of the international trade this negatively affects the reliability of efficiency assessment of the international trade activity by a business entity.

The development of international trade strategy by business entities with the purpose of creating an economic growth reserve requires new approaches to assessment of international trade efficiency; in this connection, the system of the international trade contract analysis needs to be established. Such system should take into account the influence of a changing environment, long-term consequences of management decisions and ensure economic security of a participant of the international trade. From the point of view of O. I. Vasilchuk, the problem of efficiency assessment is caused by the fact that the system based on indicators of cost efficiency and profitability allows for assessing efficiency of business only in the short-term period and in the conditions of constant relations between contractors and in the absence of asymmetry of information [7, p. 54]. It should be noted that the international trade activity is considered as an integral part of a company's production and commercial activities, and it is intended, firstly, to increase profitability of a business entity and, secondly, to ensure survival of a company under economic uncertainty. Therefore, in our opinion, the profitability increase is only one of the ways to monitor efficiency of this type of activity. Thus, the review of literature has revealed absence of the uniform method of assessment of the international trade contract efficiency in Russia at the present stage. This causes difficulties for companies in making management decisions.

The scientific challenge of sorting out contradictions between the need of a company in modern technologies of the international trade activity efficiency management, on the one hand, and imperfection of the methodology preventing 
the implementation of strategic plans in the field of the international trade, on the other hand, refers us to the methods of choosing a contract containing the best conditions for a company among all alternatives available in other countries. For objective assessment of the international trade activity efficiency, let us make a comparative analysis of the method of the Ministry of Economy of the Russian Federation [1], the method of the European Union developed on the basis of its financial regulations together with the European Development Fund [14], and the methodology by A. S. Morokov applied in the Republic of Belarus, one of the countries of the Customs Union of the Eurasian Economic Union [12], that ensure the optimal version of an international trade contract. The results obtained within the comparative study are presented in Table 1.

The analysis of the methods studied shows that each method is based on the contract condition scoring, and the criterion is an indicator selected by a company. The optimal contract is a contract with the greatest final score.

Table 1

The comparison study of the evaluation

methods of international trade contracts

\begin{tabular}{|c|c|c|c|}
\hline \multirow{2}{*}{ Parameter } & \multicolumn{3}{|c|}{ Methodology } \\
\hline & $\begin{array}{l}\text { Ministry of Economy of the } \\
\text { Russian Federation }\end{array}$ & European Union & A. S. Morokov \\
\hline 1 & 2 & 3 & 4 \\
\hline Analysis object & Contract natural indicator & $\begin{array}{l}\text { Contract natural indi- } \\
\text { cator }\end{array}$ & Contract natural indicator \\
\hline Criterion & Contract indicator & Contract indicator & Contract indicator \\
\hline $\begin{array}{l}\text { Requirement to } \\
\text { the mathematical } \\
\text { apparatus of the } \\
\text { methodology }\end{array}$ & $\begin{array}{l}\text { Indicators are quantifiable; } \\
\text { otherwise the method of ex- } \\
\text { pert evaluation is applied. }\end{array}$ & $\begin{array}{l}\text { Indicators are quanti- } \\
\text { fiable; otherwise the } \\
\text { method of expert } \\
\text { evaluation is applied. }\end{array}$ & Indicators are quantifiable. \\
\hline Ranking scale & 1 to 10 & 1 to 10 & 1 to 10 \\
\hline $\begin{array}{l}\text { Scoring of the } l^{\text {th }} \\
\text { indicator of the } \\
k^{\text {th }} \text { supplier }\end{array}$ & $\begin{array}{l}B_{k l}=1+ \\
+\frac{\left(I N_{k l}-I N_{\mathrm{Il}_{l}}\right)}{\left(I N_{\mathrm{x}_{l}}-I N_{\mathrm{I}_{l}}\right)} \times 9 ; \\
\left.\text { where } B_{k l}\right) \text { is the score of the } \\
\text { analyzed } l^{\text {th }} \text { indicator for the } \\
k^{\text {th }} \text { supplier; } \\
I N_{k l} \text { is the value of the ana- } \\
\text { lyzed } l^{\text {th }} \text { indicator measured } \\
\text { in natural units for the } k^{\text {th }} \\
\text { supplier; } \\
I N_{\mathrm{\Pi}_{l}} \text { is the worst value of } \\
\text { the analyzed } l^{\text {th }} \text { indicator } \\
\text { measured in natural units } \\
\text { among possible of all suppli- } \\
\text { ers; } \\
I N_{\mathrm{x}_{l}} \text { is the best value of the } \\
\text { analyzed } l^{\text {th }} \text { indicator meas- } \\
\text { ured in natural units among } \\
\text { possible of all suppliers. }\end{array}$ & $\begin{array}{l}\text { 1) if } I N_{\mathrm{\Pi}_{l}}<I N_{\mathrm{x}_{l}}, \text { then } \\
B_{k l}=10 \times \frac{I k_{k l}}{I N_{\mathrm{x}_{k l}}} \text {; } \\
\text { 2) if } I N_{\mathrm{\Pi}_{l}}>I N_{\mathrm{x}_{l}}, \text { then } \\
B_{k l}=10 \times \frac{I N_{\mathrm{x}_{k l}}}{I N_{k l}} \text {. }\end{array}$ & 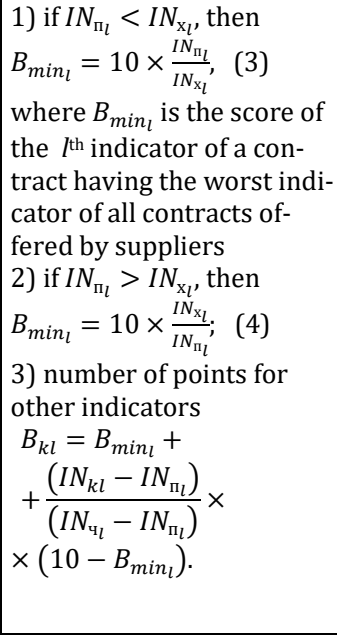 \\
\hline
\end{tabular}


Table 1 continued

\begin{tabular}{|c|c|c|c|}
\hline \multirow[t]{2}{*}{ Parameter } & \multicolumn{3}{|c|}{ Methodology } \\
\hline & $\begin{array}{l}\text { Ministry of Economy of } \\
\text { the Russian Federation }\end{array}$ & European Union & A. S. Morokov \\
\hline 1 & 2 & 3 & 4 \\
\hline $\begin{array}{l}\text { Ranking assigned } \\
\text { to the worst indi- } \\
\text { cator }\end{array}$ & $\begin{array}{l}1 \text { point is automatically } \\
\text { assigned to an indicator } \\
\text { with the worst value } \\
\text { among all suppliers. }\end{array}$ & $\begin{array}{l}\text { The minimum num- } \\
\text { ber of points, there- } \\
\text { with the estimate } \\
\text { value may be any } \\
\text { value in the interval } \\
\text { of } 0 \text { to } 10 \text { calculated } \\
\text { by the formula (1) or } \\
(2) .\end{array}$ & $\begin{array}{l}\text { The minimum number of } \\
\text { points calculated by the for- } \\
\text { mula (3) or (4) taking into ac- } \\
\text { count a scale of differences in } \\
\text { natural indicator values of } \\
\text { contracts for each criterion. }\end{array}$ \\
\hline $\begin{array}{l}\text { Ranking assigned } \\
\text { to the best indica- } \\
\text { tor }\end{array}$ & $\begin{array}{l}10 \text { points are automati- } \\
\text { cally assigned to an indi- } \\
\text { cator with the best value } \\
\text { among all suppliers. }\end{array}$ & $\begin{array}{l}10 \text { points derived } \\
\text { from calculation un- } \\
\text { der formula (1) or }(2)\end{array}$ & $\begin{array}{l}10 \text { points are automatically } \\
\text { assigned to an indicator with } \\
\text { the best value among all sup- } \\
\text { pliers. }\end{array}$ \\
\hline $\begin{array}{l}\text { Final ranking of a } \\
\text { contract of the } k^{\text {th }} \\
\text { supplier }\end{array}$ & $\begin{array}{l}B_{k_{\text {total }}}=\sum_{l=1}^{n} \alpha_{l} \times B_{k l} \leq \\
\leq 10, \\
\text { where } \alpha_{l} \text { is the ratio de- } \\
\text { termining the relative } \\
\text { share of the } l^{\text {th }} \text { criterion } \\
\text { by its importance in the } \\
\text { procedure of choosing } \\
\text { the optimal contract } \\
\text { among other criteria; } \\
n \text { is the number of criteria } \\
\text { used in contract evalua- } \\
\text { tion }\end{array}$ & $\begin{array}{l}B_{k_{\text {total }}}=\sum_{l=1}^{n} \alpha_{l} \times B_{k l} \\
\leq \\
\leq 10, \\
\text { where } \alpha_{l} \text { is the ratio } \\
\text { determining the rela- } \\
\text { tive share of the }{ }^{\text {th }} \\
\text { criterion by its im- } \\
\text { portance in the pro- } \\
\text { cedure of choosing } \\
\text { the optimal contract } \\
\text { among other criteria; } \\
n \text { is the number of } \\
\text { criteria used in con- } \\
\text { tract evaluation }\end{array}$ & $\begin{array}{l}\quad B_{k_{\text {total }}}=\sum_{l=1}^{n} \alpha_{l} \times B_{k l} \leq \\
\leq 10, \\
\text { where } \alpha_{l} \text { is the ratio deter- } \\
\text { mining the relative share of } \\
\text { the } l^{\text {th }} \text { criterion by its im- } \\
\text { portance in the procedure of } \\
\text { choosing the optimal contract } \\
\text { among other criteria; } \\
n \text { is the number of criteria } \\
\text { used in contract evaluation }\end{array}$ \\
\hline Optimal contract & $\begin{array}{l}\text { The contract that re- } \\
\text { ceived the highest final } \\
\text { score in points }\end{array}$ & $\begin{array}{l}\text { The contract that re- } \\
\text { ceived the highest fi- } \\
\text { nal score in points }\end{array}$ & $\begin{array}{l}\text { The contract that received } \\
\text { the highest final score in } \\
\text { points }\end{array}$ \\
\hline $\begin{array}{l}\text { Characteristic } \\
\text { curve }\end{array}$ & $\begin{array}{l}\text { Linear distribution of es- } \\
\text { timates based on contract } \\
\text { indexes for each criterion }\end{array}$ & $\begin{array}{l}\text { Hyperbolic distribu- } \\
\text { tion of estimates de- } \\
\text { pending on indicator } \\
\text { values of a contract } \\
\text { for each criterion }\end{array}$ & $\begin{array}{l}\text { Linear distribution of esti- } \\
\text { mates based on contract in- } \\
\text { dexes for each criterion }\end{array}$ \\
\hline Disadvantages & $\begin{array}{l}\text { Distribution of estimates } \\
\text { is very sensitive to a } \\
\text { value of indicator disper- } \\
\text { sion range measured in } \\
\text { natural values of a con- } \\
\text { tract for each criterion }\end{array}$ & $\begin{array}{l}\text { A large number of } \\
\text { calculations leading } \\
\text { to errors in final re- } \\
\text { sults }\end{array}$ & $\begin{array}{l}\text { Complexity of calculations } \\
\text { that may lead to mistakes } \\
\text { contributing to the final re- } \\
\text { sult }\end{array}$ \\
\hline Advantages & $\begin{array}{l}\text { - easy calculations; } \\
\text { - visual expression } \\
\text { of results; } \\
\text { - ability of the method } \\
\text { automation allowing to } \\
\text { carry out scoring of con- } \\
\text { tract indicators; }\end{array}$ & $\begin{array}{l}\text { - distribution of esti- } \\
\text { mates has allowable } \\
\text { sensitivity to the con- } \\
\text { tract indexes disper- } \\
\text { sion range for each } \\
\text { criterion; } \\
\text { - ability of the } \\
\text { method automation } \\
\text { allowing to carry out } \\
\text { scoring of contract } \\
\text { indicators; }\end{array}$ & $\begin{array}{l}\text { - distribution of estimates has } \\
\text { allowable sensitivity to the } \\
\text { contract indexes dispersion } \\
\text { range for each criterion; } \\
\text { - ability of the method auto- } \\
\text { mation allowing to carry out } \\
\text { scoring of contract indicators; } \\
\text { - } B_{\text {min }_{l}} \text { is the value in relation } \\
\text { to which scoring is made for } \\
\text { the contract indicators pro- } \\
\text { posed by suppliers exceeding } \\
B_{\text {min }} \text { that ensures accurate } \\
\text { estimation of a particular } \\
\text { contract. }\end{array}$ \\
\hline
\end{tabular}


The source: prepared by the author using [11, p. 75-78]

Activities under uncertainty, in our opinion, make a company use a toolware to identify suppliers in competitive ways. We believe that in order to solve this problem a business entity may apply any of the methods considered above.

To confirm this conclusion, we can represent its practical implementation as a case study of a brewer purchasing premium beer abroad. An importer upon receiving an offer from six foreign suppliers should choose from the offered variants the optimum contract for premium beer purchases using the offer price as the criterion. Applying the methods of the Ministry of Economy of the Russian Federation, the European Union and by A. S. Morokov a company can obtain different results as it is shown in Table 2.

Table 2

The selection of the optimal import contract by a company

\begin{tabular}{|c|c|c|c|c|}
\hline \multirow{3}{*}{ Supplier } & Criterion & \multicolumn{3}{|c|}{ Ranking, score } \\
\cline { 2 - 5 } & $\begin{array}{c}\text { Purchase } \\
\text { price, }\end{array}$ & \multicolumn{3}{|c|}{ Methods } \\
\cline { 3 - 5 } & Euro/L & $\begin{array}{c}\text { Ministry of Econ- } \\
\text { omy of the Russian } \\
\text { Federation }\end{array}$ & $\begin{array}{c}\text { European } \\
\text { Union }\end{array}$ & A. S. Morokov \\
\hline I & 13.00 & 10.00 & 10.00 & 10.00 \\
\hline II & 17.00 & 7.75 & 7.65 & 8.62 \\
\hline III & 22.00 & 4.94 & 5.91 & 5.90 \\
\hline IV & 25.00 & 3.25 & 5.2 & 5.52 \\
\hline V & 26.00 & 2.69 & 5.0 & 4.48 \\
\hline VI & 29.00 & 1.00 & 4.48 & \\
\hline
\end{tabular}

The analysis of Table 2 shows that according to the criterion of the premium beer purchase price the optimal contract for a company is that under conditions offered by Supplier I, while unacceptable conditions for an importer is contained in the commercial offer of Supplier VI. The graphic interpretation of the obtained results is shown in Figure 1.

As in the international trade a price of goods continues to be an indicator influencing decisions to conclude a contract, the methods specified by Article 22, Part 1 of Federal Law No. 44-FZ of April 05, 2013 may be used for its substantiation [4], that does not eliminates a possibility of applying other methods. There may be situations when one of the parties of a future agreement requires to specify a price formula therein. In this case when entering into an international trade contract, a company should be guided not only by Government Decree No.19 of January 13, 2014 [6], but also by the international law.

It should be noted that instead of the price a company may use the goods life cycle as the estimation criterion of offers, including the cost of its purchase, transportation, pre-sale preparation, subsequent maintenance, repair and disposal, that does not contradict to Clause 3, Article 32 of Federal Law No.44-FZ of April 05, 2013 [4]. The cases when a life cycle contract should be concluded are determined by Government Decree No.1087 of November 28, 2013 [5], and its cost for goods may be calculated in accordance with Part 20 of Article 22 of Federal Law No.44-FZ of April 05, 2013 [4]. 


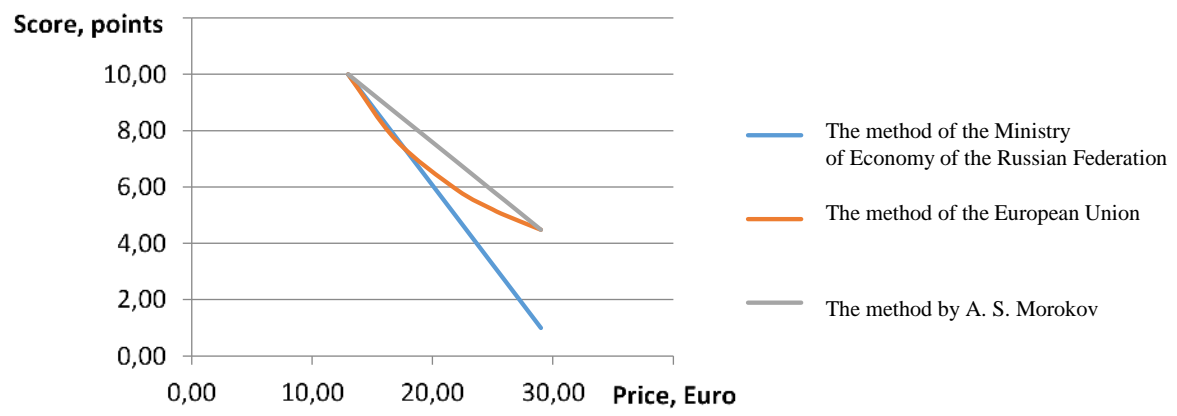

Figure 1. The distribution of estimates of the import contract indicator by the Price criterion

Under uncertainty the companies having chosen a contract the most completely corresponding to their strategies are not immune to a situation when a foreign supplier can refuse to sign it. In this case, an importer guided by Clause 4 of Article 54 of Federal Law No 44-FZ of April 05, 2013 [4] and the conclusions contained in a number of scientific papers, for example, by O. I. Vasilchuk, N. K. Muravitskaya [8, P. 40] selects the contract of the supplier ranked second among all the bids. However, this is not the right solution as scoring of contracts left after removal of the supplier proposed the best conditions to a company may result in that the optimal contract is one that initially was ranked lower than number two.

In the following example, it is confirmed that distribution of points will be different after re-evaluation of the suppliers' offers without a contract recognized as the best one during the initial evaluation. The data of an importer of premium beer under the international trade contracts are used as an information base for calculations. Table 3 shows the commercial offers of four foreign suppliers for which a company has chosen natural indicators of contracts according to their weighting coefficients as evaluation criteria. Scoring is based on the method developed on the basis of the Financial regulations of the European Union and the European Development Fund. The values of weighting coefficients of criteria are defined on the basis of the business practice of the company in procurement from different suppliers.

The analysis of the obtained data shows that the optimal conditions for a company are included into the contract proposed by Supplier I, which has the final score 8.4. The offer ranked second is the offer of Supplier II. The re-evaluation, according to the methodology of the European Union, of foreign suppliers' offers excluding the contract of Supplier I that refused to enter into the agreement for supply of premium beer with the company, gives the results presented in Table 4. The analysis of this table shows that if Supplier I is removed, the optimal contract may be offered by Supplier III that received 7.6 points during reevaluation against 7.3 points for Supplier II. 
$5^{\text {th }}$ International Conference «Economy modernization: new challenges and innovative practice»

Table 3

The initial evaluation of import contracts

\begin{tabular}{|l|c|c|c|c|c|}
\hline \multirow{2}{*}{ Criterion/Indicator } & Weighting & \multicolumn{4}{|c|}{ Foreign supplier } \\
\cline { 3 - 6 } & coefficient & I & II & III & IV \\
\hline Purchase price, Euro/L & 0.5 & 106.40 & 76.00 & 95.00 & 190.00 \\
\hline Score by this criterion & & 7.1 & 10.0 & 8.0 & 4.0 \\
\hline $\begin{array}{c}\text { Score by this criterion con- } \\
\text { sidering } \\
\text { weighting coefficient }\end{array}$ & & 3.6 & 5.0 & 4.0 & 2.0 \\
\hline Delivery term, days & 0.2 & 12 & 19 & 23 & 11 \\
\hline Score by this criterion & & 9.2 & 5.8 & 4.8 & 10.0 \\
\hline $\begin{array}{l}\text { Score by this criterion con- } \\
\text { sidering } \\
\text { weighting coefficient }\end{array}$ & 0.3 & 1.8 & 1.2 & 1.0 & 2.0 \\
\hline Warranty period, months & & 10.2 & 4.6 & 10.6 & 12.2 \\
\hline Score by this criterion & & 3.0 & 0.8 & 1.8 & 2.0 \\
\hline $\begin{array}{c}\text { Score by this criterion con- } \\
\text { sidering } \\
\text { weighting coefficient }\end{array}$ & & 8.4 & 7.0 & 6.7 & 6.0 \\
\hline Final score & & 1 & 2 & 3 & 4 \\
\hline Ranking & & & & & \\
\hline
\end{tabular}

Table 4

The re-evaluation of contracts according to the selected criteria system

\begin{tabular}{|c|c|c|c|c|}
\hline \multirow[t]{2}{*}{ Criterion/Indicator } & \multirow{2}{*}{$\begin{array}{l}\text { Weighting } \\
\text { coefficient }\end{array}$} & \multicolumn{3}{|c|}{ Foreign supplier } \\
\hline & & II & III & IV \\
\hline Purchase price, Euro/L & 0.5 & 76.00 & 95.00 & 190.00 \\
\hline Score by criterion & & 10.0 & 8.0 & 4.0 \\
\hline $\begin{array}{l}\text { Score by criterion consider- } \\
\text { ing } \\
\text { weighting coefficient }\end{array}$ & & 5.0 & 4.0 & 2.0 \\
\hline Delivery term, days & 0.2 & 19 & 23 & 11 \\
\hline Score by criterion & & 5.8 & 4.8 & 10.0 \\
\hline $\begin{array}{l}\text { Score by criterion consider- } \\
\text { ing } \\
\text { weighting coefficient }\end{array}$ & & 1.2 & 1.0 & 2.0 \\
\hline Warranty period, months & 0.3 & 4.6 & 10.6 & 12.2 \\
\hline Score by criterion & & 3.8 & 8.7 & 10.0 \\
\hline $\begin{array}{l}\text { Score by criterion consider- } \\
\text { ing } \\
\text { weighting coefficient }\end{array}$ & & 1.1 & 2.6 & 3.0 \\
\hline Final score & & 7.3 & 7.6 & 7.0 \\
\hline Ranking & & 2 & 1 & 3 \\
\hline
\end{tabular}


The differences in the results can be explained by the fact that, firstly, scoring in the method of the European Union is calculated according to different formulas. In the formula (1) shown in Table 1 the $I N_{k l}$ index is in the numerator, and in the expression (2) in the denominator, which indicates the linear distribution of points in the first case, and the hyperbolic dependence of natural indicator values from their scores in the second case. Secondly, an import contract containing the conditions optimal for the company's strategy that is expressed by the maximum final score may not only have the best value, but also the worst value, or the value between these values of a natural indicator. Therefore, depending on what value of an indicator is excluded from consideration, each of the two situations described above has three scenarios, the analysis of which is carried out below.

Calculations of scoring by the methods of the European Union, the Ministry of Economy of the Russian Federation and A. S. Morokov for all commercial offers including the cases corresponding to exception of a contract with the best value of the criterial indicator, a contract with intra-range value of this indicator, and a contract with the worst value from the analysis give an opportunity to form Table 5.

The analysis of Table 5 shows that, for a case excluding an import contract with the best conditions for a company from consideration, it is more appropriate for an importer to accept the contract proposed by Supplier III if the criterial indicator is the price of premium beer purchase.

It should be noted that in this case, the evaluation of the contract proposed by Supplier III increases for two points, and scoring of the Supplier IV offer increases for only one point indicating the non-linear distribution of estimates.

If a company selects a goods delivery term as a criterial indicator, then in case of the refusal of Supplier IV to sign a contract, it is desirable for an importer to deal with Supplier I. The situation is opposite when a business entity chooses the guarantee term provided by a foreign supplier as a criterion for evaluation of import contracts. In this case, the score of the Supplier II offer increases for 1.3 points; the scores of the contracts of Suppliers III and IV increase for 2.9 and 3.3 points, respectively, that indicates the non-linear distribution of natural indicators scores.

Table 5

The evaluation of import contracts according to the methods under study

\begin{tabular}{|c|c|c|c|c|c|c|c|c|c|c|c|c|}
\hline $\begin{array}{c}\text { Method- } \\
\text { ology }\end{array}$ & & $\mathrm{y}$ & c & & & rop & & & & S. & & \\
\hline \multirow[t]{2}{*}{ Criterion } & \multicolumn{4}{|c|}{ Foreign supplier } & \multicolumn{4}{|c|}{ Foreign supplier } & \multicolumn{4}{|c|}{ Foreign supplier } \\
\hline & I & II & III & IV & I & II & III & IV & I & II & III & IV \\
\hline \begin{tabular}{|l|} 
Purchase \\
price \\
specified \\
in the in- \\
itial of- \\
fer, \\
Euro/L \\
\end{tabular} & $\begin{array}{l}\stackrel{9}{1} \\
\stackrel{0}{0}\end{array}$ & \begin{tabular}{l}
8 \\
\hdashline
\end{tabular} & $\begin{array}{l}8 \\
\text { బू }\end{array}$ & ஓ. & $\begin{array}{l}9 \\
\text { g } \\
0\end{array}$ & $\begin{array}{l}8 \\
0\end{array}$ & ผू & $\begin{array}{l}8 \\
\stackrel{+}{\circ} \\
\end{array}$ & \begin{tabular}{l}
9 \\
\multirow{2}{1}{} \\
0
\end{tabular} & @̊ & น & ஃ. \\
\hline
\end{tabular}


Table 5 continued

\begin{tabular}{|c|c|c|c|c|c|c|c|c|c|c|c|c|}
\hline \multirow{3}{*}{\begin{tabular}{|c|}
$\begin{array}{c}\text { Method- } \\
\text { ology }\end{array}$ \\
Criterion \\
\end{tabular}} & \multicolumn{4}{|c|}{$\begin{array}{l}\text { Ministry of Economy of } \\
\text { the Russian Federation }\end{array}$} & \multicolumn{4}{|c|}{ European Union } & \multicolumn{4}{|c|}{ A. S. Morokov } \\
\hline & \multicolumn{4}{|c|}{ Foreign supplier } & \multicolumn{4}{|c|}{ Foreign supplier } & \multicolumn{4}{|c|}{ Foreign supplier } \\
\hline & $\mathrm{I}$ & II & III & IV & I & II & III & IV & I & II & III & IV \\
\hline \begin{tabular}{|l|} 
Score by \\
this crite- \\
rion at: \\
\end{tabular} & & & & & & & & & & & & \\
\hline \begin{tabular}{|l|} 
- Initial \\
offer
\end{tabular} & $\begin{array}{l}0 \\
\end{array}$ & 우 & 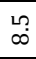 & - & $\stackrel{-}{\pi}$ & 욱 & $\infty$ & H & $\stackrel{+}{\infty}$ & 욱 & $\sigma$ & + \\
\hline \begin{tabular}{|l|}
- removal \\
of a sup- \\
plier with \\
the best \\
condi- \\
tions \\
of a con- \\
tract \\
\end{tabular} & $\stackrel{\infty}{\infty}$ & ' & $\stackrel{\circ}{\sim}$ & - & ${ }_{\infty}^{\infty}$ & ' & 욱 & เ & హ゙ & ' & $\stackrel{9}{-1}$ & เ \\
\hline \begin{tabular}{|l|} 
- removal \\
of a sup- \\
plier with \\
an offer \\
with pa- \\
rameters \\
within \\
the range \\
\end{tabular} & ' & $\stackrel{?}{?}$ & 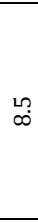 & $r$ & ' & $\stackrel{?}{\sim} \cdot(-1)$ & $\infty$ & $\theta$ & & $\stackrel{\circ}{\sim}$ & $\sigma$ & t \\
\hline \begin{tabular}{|l|}
- removal \\
of a sup- \\
plier with \\
the worst \\
condi- \\
tions \\
of a con- \\
tract \\
\end{tabular} & -1 & $\stackrel{?}{\rightarrow}$ & $\stackrel{+}{+}$ & ' & $\stackrel{7}{n}$ & $\stackrel{9}{\rightarrow}(-1)$ & $\infty$ & ' & $\stackrel{-7}{\pi}$ & $\stackrel{9}{\rightarrow}(-1)$ & $\stackrel{N}{\infty}$ & ' \\
\hline \begin{tabular}{|l|} 
Delivery \\
term \\
specified \\
in the in- \\
itial of- \\
fer, days
\end{tabular} & บ & $\stackrel{\sigma}{\sim}$ & $\approx$ & $\exists$ & ㄱ & $\approx$ & 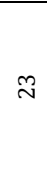 & $\exists$ & $\mathcal{7}$ & $\stackrel{\sim}{\sim}$ & $\stackrel{m}{N}$ & $\exists$ \\
\hline \begin{tabular}{|l|}
$\begin{array}{l}\text { Score by } \\
\text { this crite- } \\
\text { rion at: }\end{array}$ \\
\end{tabular} & & & & & & & & & & & & \\
\hline \begin{tabular}{|l|} 
- Initial \\
offer
\end{tabular} & $\stackrel{m}{\sigma}$ & H & - & $\stackrel{ }{\circ}$ & ๙ั & $\stackrel{\infty}{\llcorner}$ & $\stackrel{\infty}{+}$ & $\stackrel{\circ}{\sim}$ & $\stackrel{0}{\sigma}$ & ᄂึ? & $\stackrel{\infty}{+}$ & $\stackrel{ㅇ}{\rightarrow}$ \\
\hline \begin{tabular}{|l|} 
- removal \\
of a sup- \\
plier with \\
the best \\
condi- \\
tions \\
of a con- \\
tract
\end{tabular} & $\stackrel{9}{\sim}$ & $\stackrel{m}{\rightarrow}$ & - & & 우 & M & ஸี่ & & $\stackrel{9}{9}$ & $n$ & ก้ & ' \\
\hline \begin{tabular}{|l|} 
- removal \\
of a sup- \\
plier with \\
an offer \\
with pa- \\
rameters \\
within \\
the range \\
\end{tabular} & $\sigma^{m}$ & ' & -1 & $\stackrel{ }{\sim}$ & ๙ู & & 市 & $\stackrel{ }{\sim}$ & $\stackrel{0}{\circ}$ & & $\stackrel{\infty}{+}$ & $\stackrel{\circ}{\sim}$ \\
\hline
\end{tabular}


Table 5 continued

\begin{tabular}{|c|c|c|c|c|c|c|c|c|c|c|c|c|}
\hline $\begin{array}{l}\text { Method- } \\
\text { ology }\end{array}$ & & try & $\mathrm{COr}$ & $\begin{array}{l}\text { y of } \\
\text { ion }\end{array}$ & & rop & Uni & & & & oko & \\
\hline \multirow[t]{2}{*}{ Criterion } & \multicolumn{4}{|c|}{ Foreign supplier } & \multicolumn{4}{|c|}{ Foreign supplier } & \multicolumn{4}{|c|}{ Foreign supplier } \\
\hline & I I & II & III & IV & I & II & III & $\mathrm{IV}$ & I & II & III & IV \\
\hline \begin{tabular}{|l|} 
- removal \\
of a sup- \\
plier with \\
the worst \\
condi- \\
tions \\
of a con- \\
tract
\end{tabular} & ${ }_{\infty}^{\infty}$ & -1 & ' & 욱 & ๙ & $\stackrel{\infty}{i \infty}$ & & 우 & 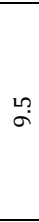 & in & & $\stackrel{\sim}{\sim}$ \\
\hline \begin{tabular}{|l|} 
War- \\
ranty pe- \\
riod \\
specified \\
in the in- \\
itial of- \\
fer, \\
months
\end{tabular} & $\stackrel{N}{\infty}$ & $\stackrel{\bullet}{+}$ & $\stackrel{0}{0}$ & $\stackrel{\text { I }}{\mathrm{J}}$ & $\stackrel{N}{\infty}$ & $\stackrel{\circ}{+}$ & 递 & ลี & $\stackrel{N}{\infty}$ & $\stackrel{\circ}{+}$ & 递 & $\stackrel{\tilde{I}}{\exists}$ \\
\hline $\begin{array}{l}\text { Score by } \\
\text { this crite- } \\
\text { rion at: }\end{array}$ & & & & & & & & & & & & \\
\hline $\begin{array}{l}\text { - Initial } \\
\text { offer }\end{array}$ & 욱 & -1 & L & 0 & 욱 & 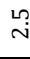 & $\stackrel{\infty}{\llcorner}$ & $\hat{\jmath}$ & 욱 & 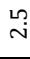 & $\stackrel{\infty}{i n}$ & $\hat{\emptyset}$ \\
\hline \begin{tabular}{|l|} 
- removal \\
of a sup- \\
plier with \\
the best \\
condi- \\
tions \\
of a con- \\
tract \\
\end{tabular} & ' & -1 & $\vec{\infty}$ & $\stackrel{\circ}{\sim}$ & ' & $\stackrel{\infty}{\sim}$ & 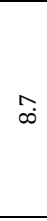 & $\stackrel{ }{\rightarrow}$ & ' & $\stackrel{\infty}{m}$ & $\widehat{\infty}$ & $\stackrel{ }{\sim}$ \\
\hline \begin{tabular}{|l|} 
- removal \\
of a sup- \\
plier with \\
an offer \\
with pa- \\
rameters \\
within \\
the range \\
\end{tabular} & 욱 & -1 & n & & $\stackrel{\circ}{\sim}$ & $\stackrel{\llcorner}{N}$ & $\stackrel{\infty}{\llcorner}$ & ' & 욱 & $\stackrel{L n}{N}$ & $\stackrel{\infty}{i}$ & ' \\
\hline \begin{tabular}{|l|} 
- removal \\
of a sup- \\
plier with \\
the worst \\
condi- \\
tions \\
of a con- \\
tract \\
\end{tabular} & 우 & ' & -1 & $\hat{\mathrm{N}}$ & $\stackrel{-}{\sim}$ & ' & in & $\widehat{\vartheta}$ & 우 & & $\stackrel{\infty}{\omega}$ & $\hat{\sigma}$ \\
\hline
\end{tabular}

The source: calculated by the author

The results obtained after re-evaluation differ from the results of initial analysis of import contract terms. It may be explained as follows. The performed analysis of import contracts using the Warranty Period criterion excludes from consideration the contract proposed by Supplier I with the best indicator among all suppliers under this criterion.

The score increment under the contract of Supplier III is 0.3 points, while the Supplier II offer has this value as 0.8 points. Therefore, the difference between increments of import contracts of the suppliers' score is equal to 0.5 points. Since the score reserve of all criteria at initial offering was 0.3 points, it can be argued that the offer of Supplier II has the reserve of 0.3 points over the 
offer of Supplier III. When the remaining offers are re-evaluated, the score reserve of all criteria is 0.3 points, which indicates that the final score of the Supplier III contract exceeds over the final score of the Supplier II offer.

According to the mentioned above, the following conclusions can be made:

1) The final score of an import contract is formed by summing up the scores for each criterion taking into account their weighting coefficients.

2) In the case of exclusion of a contract that has the best indicator of all alternatives for a particular indicator from consideration, the scores for remaining bids change that results in the changes of ranking distribution.

3) If the analysis excludes an indicator that does not have the best ranking by this criterion, the scores for remaining offers do not change, so the distribution of their ranks remains the same.

4) The necessary condition for preserving the ranks obtained by commercial offers during the initial evaluation is equality to zero of difference of increments of their points.

Since the necessary condition of the European Union method is not met, the analysis of import contracts is carried out according to the method proposed by the Ministry of Economy of the Russian Federation. The values of the received scores are different from estimates found according to the European Union method, which leads to other conclusions. Thus, the analysis of the data presented in Table 5 states the different behaviour of estimates corresponding to the cases of exclusion from consideration of the best indicator relating to a contract with optimal conditions for a company, and the worst of all supplier offers, which can lead to errors in calculating.

In our opinion, the method proposed by A. S. Morokov gives an opportunity to avoid mistakes which can take place in the evaluation of import contracts according to the method of the Ministry of Economy of the Russian Federation [12]. The analysis of the obtained results suggests that application of this method for evaluation of contracts, if the best value of its worst indicator is exceeded, results in the changes in estimates if the analysis excludes the best indicator. If the worst value of the indicator exceeds its best value, then if the worst indicator is excluded from the study, the score also changes. If the best value is excluded from the analysis for the case in which its worst value exceeds the best value, there is no change in the distribution of estimates for the selected criterion, because the difference between increments of the scoring of foreign suppliers offers equals to zero.

Summarizing the results of the analysis, it can be stated that none of the methods can reliably define the optimal import contract during repeated scoring of commercial offers, in the case of the refusal of a supplier that proposed the best conditions to a company to sign a contract. In our opinion, an adequate result may be obtained by using the method by A. S. Morokov, as the necessary condition for preserving the distribution of scores when the best indicator is excluded from the analysis is met.

We believe that a company concluding import contracts for purchase of goods within its business activity that it carries out at its own risk can apply the considered methods to develop the toolware enabling it already at the stages of the offer analysis to identify the actions of an unfair supplier that is forced to conclude contracts not only through the proposal of win conditions to the parties of the potential transaction, but also taking various actions to gain the trust of the buyer due to conditions of uncertainty prevailing in the international market. 
An example of such operations is a supplier's offer containing conditions that it fails to fulfil due to the lack of production capacity, storage space, and specialists of the corresponding level. Relevance of this problem is caused by the fact that recently in the beer industry there were cases when commercial offers were made to a buyer by the companies not officially affiliated, but actually one of them was created by a supplier only for concluding a contract in account of forming a offer not only at the level of customer's requirements but exceeding thereof.

Substantiation of this statement is the results of the analysis conducted in order to identify possible manipulations of the foreign supplier (Supplier VI) with the parameters of import contracts proposed to a company (see Table 6). Import contracts proposed by six potential suppliers were evaluated on the basis of the scoring methods of the European Union, the Ministry of Economy of the Russian Federation and A. S. Morokov according to such criteria as a delivery price, delivery terms and a warranty period. The analysis of Table 6 shows that, since Supplier III is a company created by Supplier VI to increase its competitiveness in the Warranty Period criterion against its competitors, but actually not having such level of competitiveness; it creates a new offer with the warranty period of 45 months, as it is evidenced by the results of the evaluation of import contracts taking into account changes in the conditions introduced by Supplier III in the offer presented in the same table.

Table 6

The evaluation of import contracts for identification of fake foreign suppliers

\begin{tabular}{|c|c|c|c|c|c|c|c|c|c|c|c|c|}
\hline \multirow{3}{*}{$\begin{array}{l}\text { Contract version } \\
\text { Criterion }\end{array}$} & \multicolumn{6}{|c|}{ Initial } & \multicolumn{6}{|c|}{ Revised } \\
\hline & \multicolumn{6}{|c|}{ Foreign supplier } & \multicolumn{6}{|c|}{ Foreign supplier } \\
\hline & $\mathrm{I}$ & II & III & IV & $\mathrm{V}$ & VI & $\mathrm{I}$ & II & III & IV & $\mathrm{V}$ & VI \\
\hline $\begin{array}{l}\text { Purchase price, } \\
\text { Euro/L }\end{array}$ & 9.12 & 7.60 & 11.40 & 9.88 & 8.36 & 11.40 & 9.12 & 7.60 & 6.30 & 9.88 & 8.36 & 11.40 \\
\hline $\begin{array}{l}\text { Score by this criterion } \\
\text { according to the } \\
\text { method: }\end{array}$ & & & & & & & & & & & & \\
\hline - the European Union & 8.3 & 10 & 6.7 & 7.7 & 9.1 & 6.7 & 6.9 & 8.3 & 10 & 6.4 & 7.5 & 5.5 \\
\hline $\begin{array}{l}\text { - Ministry of Economy } \\
\text { of the Russian Federa- } \\
\text { tion }\end{array}$ & 6.4 & 10 & 1 & 4.6 & 8.2 & 1 & 5 & 7.7 & 10 & 3.7 & 6.4 & 1 \\
\hline - A.S. Morokov & 8.7 & 10 & 6.7 & 8 & 9.3 & 6.7 & 7.5 & 8.8 & 10 & 6.8 & 8.1 & 5.5 \\
\hline Delivery term, days & 17 & 12 & 23 & 19 & 14 & 23 & 17 & 12 & 10 & 19 & 14 & 23 \\
\hline $\begin{array}{l}\text { Score by this criterion } \\
\text { according to the } \\
\text { method: }\end{array}$ & & & & & & & & & & & & \\
\hline - the European Union & 7.1 & 10 & 5.2 & 6.3 & 8.6 & 5.2 & 5.9 & 8.3 & 10 & 5.3 & 7.1 & 4.3 \\
\hline $\begin{array}{l}\text { - Ministry of Economy } \\
\text { of the Russian Federa- } \\
\text { tion }\end{array}$ & 5.9 & 10 & 1 & 4.3 & 8.4 & 1 & 5.2 & 8.6 & 10 & 3.8 & 7.2 & 1 \\
\hline - A. S. Morokov & 7.8 & 10 & 5.2 & 6.9 & 9.1 & 5.2 & 6.9 & 9.1 & 10 & 6.1 & 8.2 & 4.3 \\
\hline $\begin{array}{l}\text { Warranty period, } \\
\text { months }\end{array}$ & 30 & 24 & 15 & 18 & 36 & 15 & 30 & 24 & 45 & 18 & 36 & 15 \\
\hline $\begin{array}{l}\text { Score by this criterion } \\
\text { according to the } \\
\text { method: }\end{array}$ & & & & & & & & & & & & \\
\hline - the European Union & 8.3 & 6.7 & 4.2 & 5 & 10 & 4.2 & 6.7 & 5.3 & 10 & 4 & 8 & 3.3 \\
\hline $\begin{array}{l}\text { - Ministry of Economy } \\
\text { of the Russian Federa- } \\
\text { tion }\end{array}$ & 7.4 & 4.9 & 1 & 2.3 & 10 & 1 & 5.5 & 3.7 & 10 & 1.9 & 7.3 & 1 \\
\hline - A.S. Morokov & 8.3 & 6.7 & 4.2 & 5 & 10 & 4.2 & 6.7 & 5.3 & 10 & 4 & 8 & 3.3 \\
\hline
\end{tabular}

The source: calculated by the author 
The analysis of the obtained results shows that with the increase of a warranty period by Supplier III the scoring of Supplier IV according to the method of the Ministry of Economy of the Russian Federation does not change whereas competitors' scores decrease, but not significantly. According to the methods of the European Union and A. S. Morokov, the score of the Supplier IV offer decreases as well as the scores of other suppliers' offers.

However, as the score of the initial version of contract terms of Supplier VI according to this criterion was lower than the competitors' rankings, the value of point losses is significantly lower, only 0.9 points, than, for example, for Supplier $\mathrm{V}$, which has lost 2 points.

The study of foreign supplier offers according to the Purchase Price criterion shows that if Supplier III changes its offer by specifying the sale price at the level of 6.3 euro/L, the distribution rankings received by competitors' contracts change that is confirmed by the calculations presented in Table 6 .

At the same time the analysis of the obtained scores shows that as a result of the price decrease by Supplier III, the Supplier VI offer score according to the method of the Ministry of Economy of the Russian Federation remains at the same level, while the scores of competitor's offers decrease. It indicates that this method gives an approximate estimate.

The re-evaluation points of foreign counterparties' offers according to the method of the European Union are below the values they had initially. As the ranking of the contract was initially below than the rankings of contracts of the competitors, the value of point loss of Supplier VI in the absolute terms is less than losses of other suppliers.

The price adjustment by Supplier III led to the decrease of the scores of the indicator of all offers calculated according to the method by A. S. Morokov for 1.2 points. This means that excessive change in the value of the natural indicator of an import contract by one of the suppliers does not contribute to the change of the difference in the previously obtained scoring.

Therefore, we believe that the method by A. S. Morokov gives an opportunity to obtain adequate results of evaluation of import contracts if suppliers change the terms of commercial offers as the greatest value of the natural indicator of a contract is the worst value, and the lowest value is the best value.

The following conclusions can be drawn from compilation of the results of the study performed.

Disclosing organizational and methodological approaches to the analysis of international trade contracts, the paper argues and substantiates the need to develop a toolware to obtain reliable evaluation of international trade contracts. The demand for creation of such methodical toolware is justified, since none of the current methods of the import contract analysis does not enable a company to obtain single-value estimate for choosing an optimal import contract. The results of the conducted analysis of the final score help establish that its application in the methods of the Ministry of Economy of the Russian Federation, the European Union and A. S. Morokov for summarizing information about the parameters of contracts as a result of evaluation of alternative offers does not provide a company with all necessary information for making a management decision. 
The paper proves that the purpose of the international trade contract analysis is determined by the issues arisen. Therewith, values of criterial indicators should become objects of the separate study. This approach is reasonable as each index selected by a company as criterial one has its own information array. This can help to define the range of indicator values influencing efficiency of the international trade activity carried out by a business entity.

\section{References}

[1] About "Methodical recommendations about an efficiency evaluation of carrying out tenders on order placement on deliveries of goods for the state needs" and "The methodical recommendations about mark tender bid evaluation and qualification of the suppliers participating in tenders on order placement on deliveries of goods for the state needs" [Electronic resource]: letter of Ministry of Economics of the Russian Federation of 02.06.2000 № AC-751/4-605. Access from the legal-reference ConsultantPlus system.

[2] About introduction of amendments to article 15.25 of the Russian Federation Code of Administrative Offences [Electronic resource]: federal law of the Russian Federation of 15.02.2016 № 30-FZ: it is accepted by the State Duma of the Federal Assembly of the Russian Federation on January 29, 2016: it is approved by the Federation Council of Federal Assembly of the Russian Federation on February 10, 2016. Access from the legal-reference ConsultantPlus system.

[3] About introduction of amendments to article 4.5 of the Russian Federation Code of Administrative Offences regarding increase in prescriptive limit of administrative prosecution for violation of the foreign exchange legislation of the Russian Federation and acts of bodies of a currency control [Electronic resource]: federal law of the Russian Federation of 05.04.2016 № 89-FZ: it is accepted by the State Duma of the Federal Assembly of the Russian Federation on March 25, 2016: it is approved by the Federation Council of Federal Assembly of the Russian Federation on March 30, 2016. Access from the legal-reference ConsultantPlus system.

[4] About contractual system in the sphere of purchases of goods, works, services for ensuring the state and municipal needs [Electronic resource]: federal law of the Russian Federation of 05.04.2013 № 44-FZ (edition of 05.04.2016): it is accepted by the State Duma of the Federal Assembly of the Russian Federation 22 Mar. 2013: it is approved by the Federation Council of Federal Assembly of the Russian Federation on March 27, 2013. Access from the legal-reference ConsultantPlus system.

[5] About determination of cases of signing of the contract of lifecycle [Electronic resource]: order of the Government of the Russian Federation of 28.11.2013 № 1087. Access from the legal-reference ConsultantPlus system.

[6] About establishment of cases in which in case of signing of the contract in documentation on purchase the formula of the price and the maximum price value of the contract are specified [Electronic resource]: order of the Government of the Russian Federation of 13.01.2014 № 19. Access from the legal-reference ConsultantPlus system.

[7] Vasilchuk O.I. A technique of an efficiency evaluation of activities of accounting service on the basis of the balanced scorecard [Text] / O.I. Vasilchuk // Messenger of the Samara state economic university. - 2016. - № 4(138). - Page 54-59.

[8] Vasilchuk O.I. Management of the cost of contracts in case of the outsourcing system of servicing in the sphere of purchases of goods, works, services for ensuring the state and municipal needs [Text] / O.I. Vasilchuk, N.K. Muravitskaya // Bulletin of the Volga region state university. - Series: Economy. - 2014. - № 1(33). - Page 39-46. 
[9] Foreign economic activity of the entity: the textbook for students of higher education institutions, students on economic specialties / [L.E. Strovsky and others]; under L.E. Strovsky's edition. - The 5th edition processed and added - M.: UNITY-DANA, 2011. 503 pages.

[10] Ionova A.F. Accounting, taxation and analysis of foreign economic activity of the organization: the education guidance for students of higher education institutions / A.F. Ionova, N.A. Tarasova, N.D. Amaglobeli. - The 2 nd edition processed and added - M.: UNITY-DANA, 2011. - 415 pages.

[11] 0. V. Martyanova The rating analysis of import contracts as a method of increase in efficiency of the international trade activity of the organization in the conditions of uncertainty [Text] / O.V. Martyanova // European social science journal. - 2016. - № 5. - Page 74-99.

[12] Morokov A. S. Enhancement of techniques of mark assessment of commercial offers: basic provisions of applied researches [Electronic resource] / morokoff.com: independent project. - Access mode: https://morokoff.com/category/research/

[13] Accounting, analysis and audit of foreign economic activity: the education guidance / Under edition of professor V.I. Barilenko. - The 2nd edition - M.: INFRA-M, 2012. 368 pages - (Higher education).

[14] EUROPEN COMMISSION [Electronic resource]: official site. - Access mode: http://ec.europa.eu/internal_market/publicprocurement/ 